UDC $005.95 / .96$

Li Wei,

Postgraduate student, Sumy National Agrarian University

ORCID ID: 0000-0001-9855-229X

DOI: $10.32702 / 2306-6792.2020 .17-18.111$

\title{
RESEARCH ON SOCIAL SERVICE FUNCTIONS OF AGRICULTURAL AND FORESTRY COLLEGES AND UNIVERSITIES
}

$\Lambda$ і Вей,

аспірант, Сумський національний аграрний університет

\author{
АОСАІАЖЕННЯ СОЦІААЬНИХ ФУНКЦІЙ СІАЬСЬКОГОСПОААРСЬКИХ, АІСОВИХ \\ КОЛЕАЖІВ ТА УНІВЕРСИТЕТІВ
}

China is a big agricultural country. The problems of agriculture, rural areas and farmers have always been major issues affecting national security and stability. Chinese agricultural development is facing major challenges. In addition, China is the most populous country in the world and agricultural production is facing great pressure. However, the country has always attached great importance to agricultural development, with special emphasis on the development of agricultural science and technology. China has successively established a large number of agricultural and forestry schools to train a large number of agricultural science and technology personnel for the country. In recent years, Chinese agriculture has developed rapidly and is developing in the direction of agricultural science and technology and modernization.

The most important item in Chinese national development strategy is the comprehensive elimination of the poor and the vast rural population is an important target for this work. This means that Chinese agricultural universities and a large number of agricultural talents are facing major development opportunities. The vast number of agricultural and forestry colleges and universities should make full use of their own resources such as science and technology and talents to provide technology, services, products, etc. The exertion of social functions in agricultural and forestry colleges and universities should fully consider the relationship between colleges and major stakeholders.

In this context, this paper explores the basic situation of the development and construction of agricultural and forestry universities in China. This paper also studies the problems existing in the development of agricultural and forestry universities and professional education. The basic situation of the number of college students majoring in agriculture and forestry was studied. It studies the development trend of Chinese agriculture and the basic content of social services of Chinese agricultural colleges. And put forward suggestions for them to better realize the social service function.

Китай - велика сільськогосподарська країна. Проблеми розвитку сільського господарства, сільської місцевості та фермерів завжди були найважливішими проблемами, що впливають на національну безпеку, стабільність. Розвиток сільського господарства Китаю має значну кількість проблем, попри наявність земельних угідь та інших ресурсів.

Враховуючи факт, що Китай є найбільш населеною країною у світі, відповідно, забезпечення належного розвитку сільськогосподарського виробництва є актуальним питанням. Водночас країна завжди приділяє достатню увагу сільському господарству з особливим акцентом на розвиток сільськогосподарської науки, технологій та ін. В Китаї постійно відкриваються сільськогосподарські та лісові університети, колеАжі, які забезпечують підготовку кадрів Ааної галузі. В останні роки сільське господарство Китаю почало стрімко розвиватися, модернізуватися.

Найважливішим елементом національної стратегії розвитку Китаю є всебічне подолання бідності, тому що значна частина населення цієї країни є сільським населенням. Це означає, що сільськогосподарські університети Китаю 
мають необхідні можливості та створюють сприятливу платформу Аля розвитку сільського господарства. Враховуючи означуване, значна кількість сільськогосподарських, лісових коледжів та університетів повинні повною мірою використовувати власні ресурси, як-от: наука, техніка, інші можливості, щоб забезпечити суспільство необхідними технологіями, послугами, продукцією тощо. Сільськогосподарські, лісові коледжі та університети виконують необхідні соціальні функції та враховують інтереси основних стейкхолдерів. Враховуючи зазначений контекст, у цій науковій праці досліджується питання розвитку сільськогосподарських та лісових університетів Китаю. У статті також аналізуються проблеми, які виникають у процесі розвитку сільськогосподарських, лісових університетів. Проаналізовано інформацію щодо кількості студентів у закладах освіти за спеціальністю сільське та лісове господарства. Оцінено тенденцію розвитку сільського господарства та основний зміст соціальних послуг, які надають сільськогосподарські коледжі, університети Китаю. Обгрунтовано пропозиції щодо вдосконалення соціальних функцій, які реалізують сільськогосподарські заклади освіти.

Key words: agricultural colleges and universities, social services, social service functions, agricultural modernization.

Ключові слова: сільськогосподарські коледжі та університети, соиіальні послуги, функиї сощіального обслуговування, модернізащіл сільського господарства.

\section{INTRODUCTION}

The social service function of colleges and universities is one of its important social functions. The participation of colleges and universities in social services can effectively promote social and economic development, broaden and enhance the scope and practical ability of teachers and students, promote the school's own development, and meet the needs of national social development and talent training. The Chinese government believes that colleges and universities must firmly establish the initiative to serve the society and carry out all-round services [1]. Agricultural colleges and universities are an important part of colleges and universities, which play an important role in the country's social and economic development. They need to give full play to their social service functions in agricultural development.

China is a large agricultural country with a long history and has accumulated rich experience in agricultural development. At present, Chinese agricultural development has reached the world's advanced level, and it can use $9 \%$ of the world's cultivated land to feed nearly $20 \%$ of the world's population. At present, Chinese agriculture is currently developing at a higher level, and hightech agriculture is being developed. Chinese agricultural development is characterized by intelligence, information, and ecology.

This study summarizes the basic situation of the development of agricultural and forestry universities in China and the basic situation of the number of students majoring in agriculture and forestry. Through the study of agricultural development, explore the new characteristics and new trends of Chinese agricultural development. It is expected that Chinese agricultural colleges and universities will be able to grasp the new features and trends of agricultural development and give full play to their social service functions. While promoting the development of agricultural modernization, achieve better development of it self.

\section{LITERATURE REVIEW}

The scientists and scholars who currently engaged in Social Service Functions of Agricultural Colleges and Universities mainly include: Li Zhoushan,He Guoqing, Wang Baoxing, Qiu Jing, $\mathrm{Ma} \mathrm{Yu}, \mathrm{Hu}$ Xianqi, Zheng Baoquan, Han Hai, Cheng Huadong, Chen Yushi, Su Hongwei, Jiang Zhuanhong, Wang Lu, Du Jiafang, Qiu Jing, Ma Yu, Hu Xianqi, Wu Bozhi, Lu Ziqiang.

\section{THE PURPOSE OF THE ARTICLE}

The main purpose of this article is to investigate the development and construction of agricultural and forestry universities in China and the number of students majoring in agriculture and forestry in China, study the performance of social service functions in agricultural and forestry colleges, provide suggestions for them to better play the role of social services.

\section{THE MAIN RESULTS OF THE RESEARCH}

China has a large number of agricultural and forestry universities and agricultural and forestry students. Social service function is an important social function of colleges and universities. The performance of social service functions in agricultural and forestry universities must be com- 


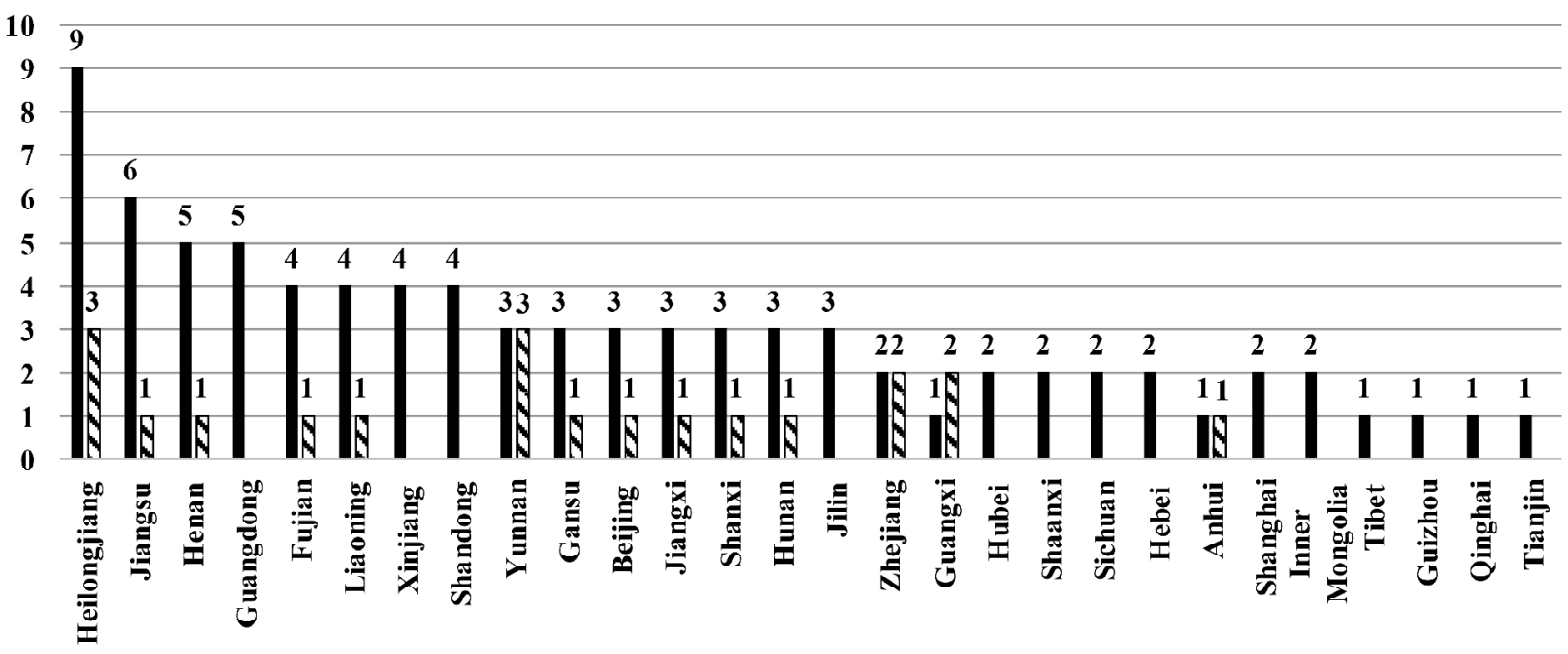

Number of agricultural colle ges

Number of forestry colleges

Figure 1. Number and distribution of agricultural and forestry colleges in China [2]

patible with economic and social development. In their social service activities, they must fully cooperate with the government, scientific research institutions, enterprises and farmers.

The author combined with a lot of research to understand the development process of college social service function in order to discover the law of the development of college social service function.

Through literature reading we found that the development of college social service functions must conform to economic and social development and adjust its development strategy along with social and economic development.

China has always attached importance to agricultural development. Since the founding of the People's Republic of China, it has vigorously supported the cultivation of agricultural science and technology talents and established a large number of agricultural and forestry colleges. Up to now, there are 80 agricultural colleges and 20 forestry colleges in China, distributed in various provinces across the country (Figure 1).

It can be seen from Figure 2 that China's agricultural and forestry universities have a large number of professional teachers, but compared with other majors, the number is relatively small, and their social service capabilities can help farmers and the countryside.

It can be seen from Figures 3 and 4 that there are a large number of students majoring in agriculture and forestry in China, but China is a large agricultural country and needs a large number of outstanding technical professionals in agriculture and forestry. Compared with other majors, the number of students is obviously inadequate. It is necessary to study how to make limited agricultural and forestry human resources play a role in society and improve their social service competence.

Although China attaches great importance to the construction of agricultural and forestry colleges and talents, there are still many problems in the development of agricultural and forestry colleges and education. The following is described from three aspects: government, school and students. The main problems in the government are the lack of attention and insufficient investment. Although the investment in agriculture and forestry education has increased compared with the previous ones, compared with other fields, this investment is not enough. Secondly, the government's agricultural industry department did not take the initiative to cooperate with universities, and failed to allow universities to make education development plans based on understanding the development of the industry. The third is that the government has not been able to actively coordinate higher agricultural and forestry education, scientific research, and the transformation and extension of achievements, which has made agricultural and forestry universities lack the enthusiasm for scientific research and affected the development of agricultural and forestry education. The problems with schools are firstly the unreasonable professional structure of disciplines and the lack of complementary advantages between agriculture and forestry majors and other majors. Secondly, agriculture and forestry colleges and universities at all levels attach importance to scale and ignore market demand and quality improvement. The third is the serious de- 


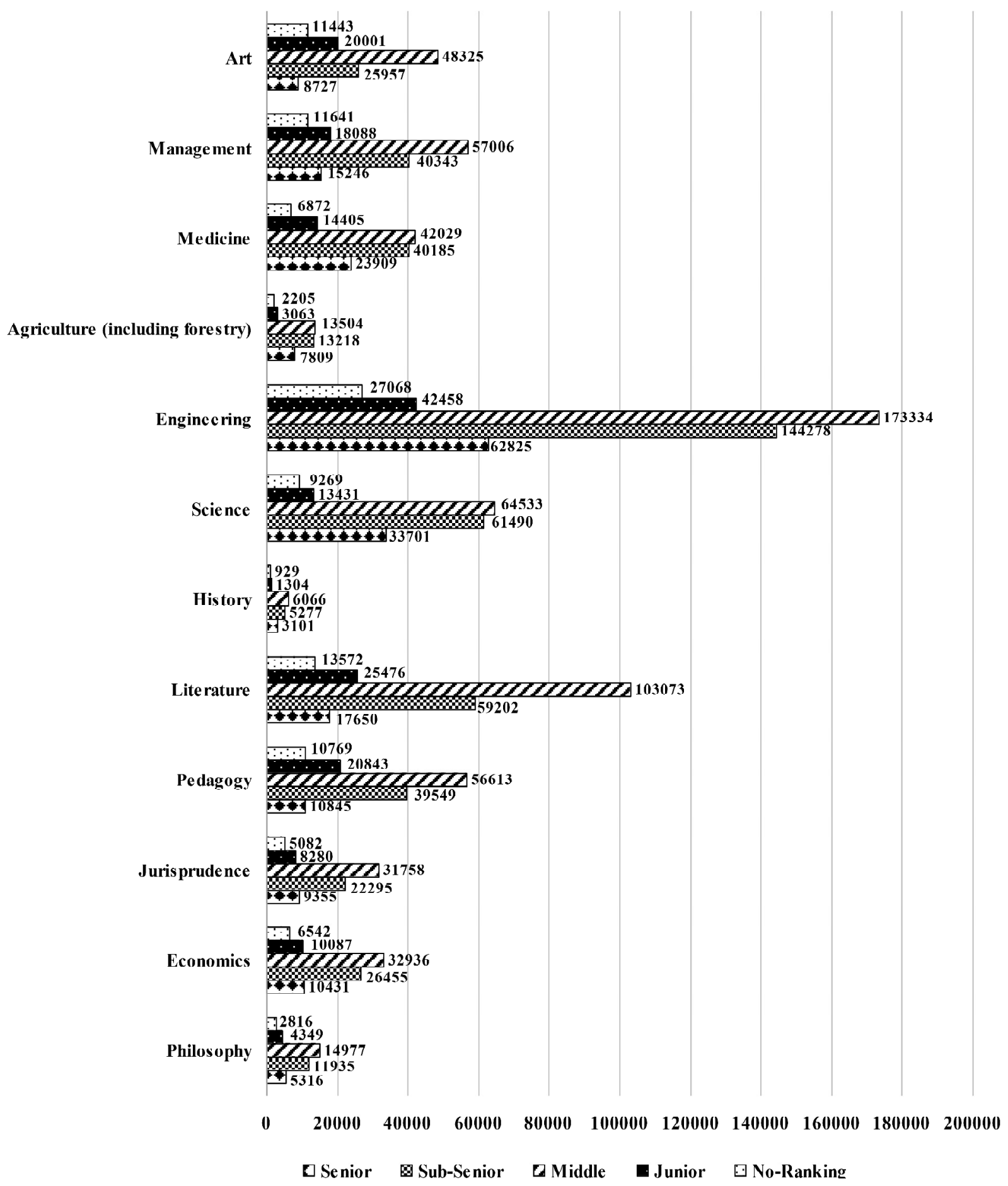

Figure 2. Number of full-time teachers in ordinary universities in China [3]

agriculturalization of majors. Many colleges and universities have added many non-agricultural majors, gradually losing the characteristics of agriculture and forestry. The fourth is that professional adjustment lags behind the development of national agriculture and forestry. Talent training cannot meet social needs. The first problem for students is the insufficient number of students. At present, in the enrollment plan of agricultural colleges, the enrollment of traditional agricultural majors is less than one third; the enrollment of agricultural majors in the country is less than $2 \%$ of the total enrollment of higher education [6]. The second is that the quality of talent training is not high, the structure is unreasonable, high-end talents such as doctors and masters are in short supply, and there is a surplus of talents in this college. The third is the difficulty of employment. 


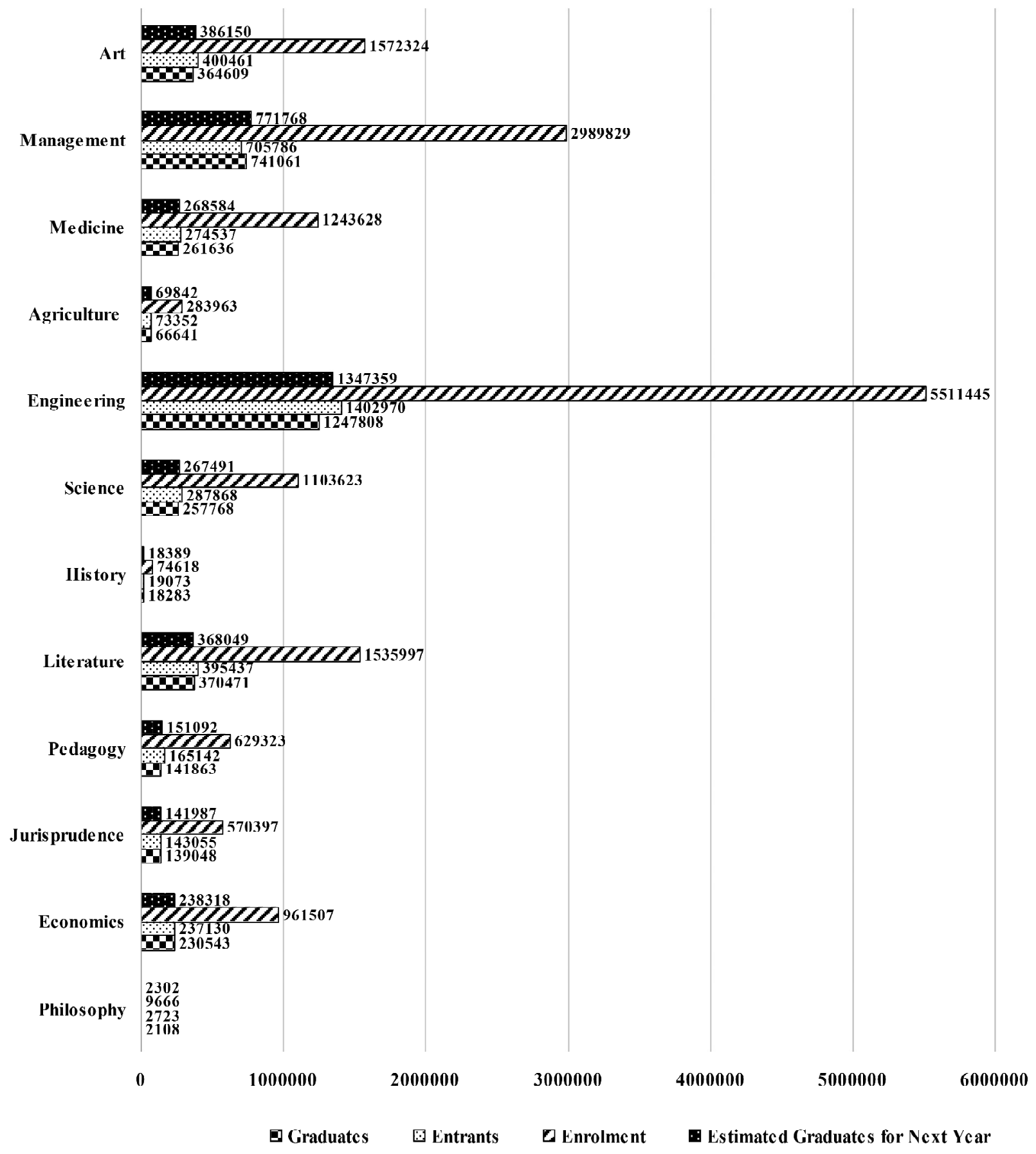

Figure 3. Number of ordinary undergraduate students in China [3]

There are many interdisciplinary jobs. Most graduates choose non-agricultural employment after graduation. Most graduates choose to work in large cities. However, there are few graduates in the vast inland rural areas in the west of the country that urgently need agricultural and forestry talents.

With the development of China's social economy, agricultural and forestry colleges also face new development issues. The current agricultural development trends to be grasped by agricultural colleges and universities include the following aspects.

The first is intelligence. The original automation and mechanization have been widely used in various fields of agriculture. At present, AI is also widely used in agricultural production. This requires universities to vigorously develop agricultural intelligent technology.

Secondly agricultural colleges and universities must enable agriculture to use the information platform to achieve large-scale development. 


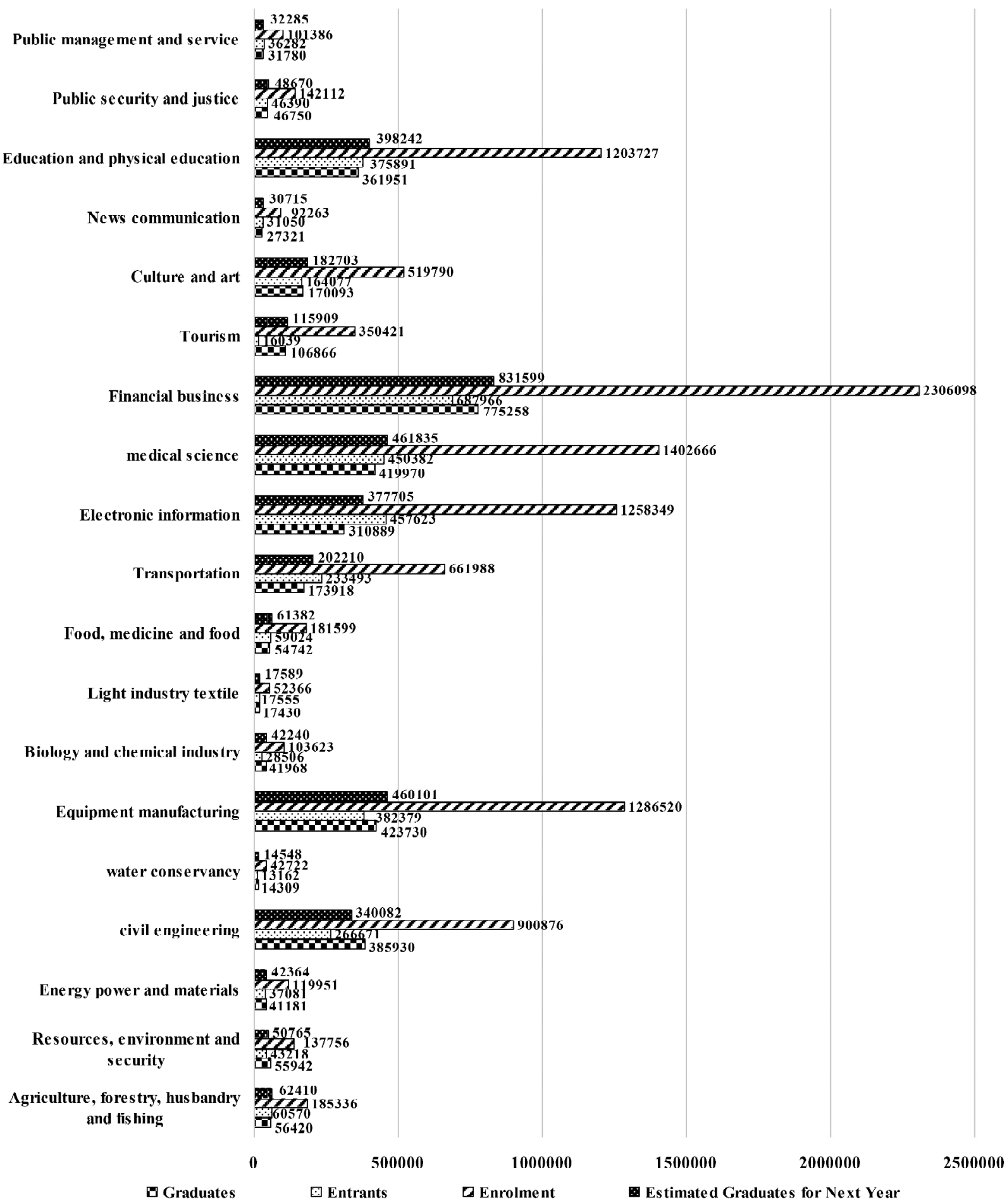

Figure 4. Number of regular students for short-cycle courses in HEls by discipline in China [3]

The third is ecological technology. In the past, the development of agriculture was relatively extensive, which even caused a significant waste of agricultural resources and a major pollution of the agricultural environment. However, in recent years, people have gradually increased their requirements for healthy and safety diets. Colleges and universities should focus on research and practice in ecological agriculture.

In face of the above new trends in agricultural and social development, agricultural colleges and universities should strive to strengthen their social service capabilities in the above fields, and carry out targeted theoretical research, technological development, and personnel training, as advocated 


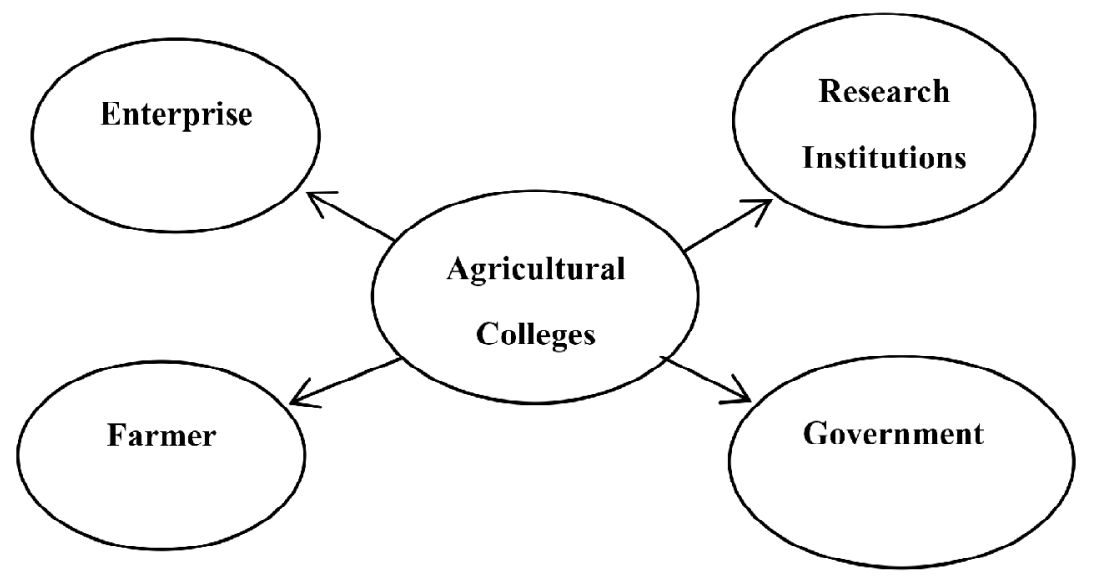

Figure 5. The role of agricultural colleges in social services

by the state and required by society. For agricultural colleges and universities to fulfill their social service functions well, they must understand their position and role in society. Only in this way can universities adapt to the requirements of social development and realize their value in promoting social development. This can also promote their own high-quality high-speed development.

Promote agricultural development through this process, while promoting self-development. The social service function of agricultural colleges and universities is the social responsibility they show in the social activities of agricultural production by providing consulting services to the society, various products and participating in activities. In order for agricultural colleges and universities to perform their functions well, they must be clear about their status and role in the execution of agricultural activities. In the course of agricultural development, agricultural colleges and universities must accurately grasp these contents in order to find opportunities in social development, to find their own development direction, and finally to realize their own social value. This will not only promote the country's agricultural development, but also achieve their own development. Combining the literature and our requirements for Chinese basic agricultural development and agricultural modernization development, we believe that the role of agricultural colleges and universities in their social service activities is shown in Figure 5.

Through Figure 5, we can clearly see the main social service activities of agricultural colleges and universities. Therefore, we believe that the following aspects are necessary for agricultural colleges and universities to better fulfill their social service functions.

First of all, agricultural universities and enterprises are closely linked. At present, the country attaches great importance to the cooperation between academies and enterprises. Agricultural technology companies at all levels provide agricultural materials, agricultural tools, agricultural services, etc. to the society through their own production and operation activities. In their production and operation activities, they need raw materials, machinery and equipment, but they also need high-tech talents and high-tech knowledge. Therefore, agricultural colleges and universities need to provide enterprises with various support through their own education and teaching, scientific research and other activities. Agricultural colleges and universities can also cooperate with enterprises through the construction of student internship training bases. They can also conduct scientific research cooperation through the joint development of agricultural science and technology projects.

The second is to strengthen the cooperation between agricultural colleges and universities and various types of agricultural scientific and technological research institutions. The cooperation between universities and scientific research institutions is mainly talent input [4], scientific and technological cooperation and information sharing. Research in the field of agricultural science and technology, but basic research in colleges and universities is solid, and the two sides can complement each other and promote common development. Colleges and universities have more scientific and technological talents, and a large number of undergraduate and graduate students who can contribute to the basic research of various projects. The university-industry-integrated model can help achieve results in scientific research.

The third is to strengthen cooperation with agricultural departments at all levels. Agricultural colleges and universities mainly provide theoretical and technical support to government 
agricultural departments and help them provide joint support in researching and formulating agricultural management systems. Colleges and universities have rich theoretical research. Combining the actual development of agriculture in the country or region, they can combine theory with practice to provide scientific theoretical basis for agricultural departments.

Finally, agricultural colleges and universities also directly provide assistance to farmers, mainly through the practice of students [5], sending technology to farmers, and other activities, targeted assistance and other methods to provide farmers with technology, information policy and other services. In particular, various colleges and universities organize social practice activities for a large number of students each year. They directly face farmers and provide them with practical help, while also improving their practical ability and improving the quality of them.

Conclusions. In this paper, the following research conclusions are obtained through research methods such as literature survey and interview. The first, China is a large traditional agricultural country and attaches great importance to the construction and development of agricultural and forestry colleges. At present, it has a large number of agricultural and forestry universities, teachers and students. Second, although the scale of higher education in agricultural and forestry universities in China is large, there are many problems in its development. The third is the rapid development of China's agriculture. At present, there are development trends in intelligentization, and ecology in agricultural development. The fourth, the social functions of agricultural and forestry colleges and universities can better promote the development of the national peasant industry, which can also promote the development of colleges and universities. The exertion of social functions in agricultural and forestry colleges and universities should fully consider the relationship between colleges and major stakeholders such as governments, farmers, enterprises and scientific research institutions.

\section{References:}

1. Ministry of Education of the People's Republic of China (2020), "Outline of the National Education Medium and Long-term Reform and Development Plan (2010-2020)", available at: http://www.moe.gov.cn/ (Accessed 25 Aug 2020).

2. China Agriculture and Forestry University (2020), "Basic situation", available at: http:// www.dxsbb.com (Accessed 25 Aug 2020).
3. Changya, Liu and Jiancong, Li (2017), China education statistics yearbook 2017, China statistics press, Beijing, China.

4. Jing, Qiu Yu, Ma and Xianqi, Hu (2019), "Experience and Enlightenment of Local Agricultural and Forestry Colleges Promoting Agricultural Modernization", Journal of Yunnan Agricultural University: Social Science, vol. 13, pp. 122-127.

5. Baoquan, Zheng and Hai, Han (2019), "Research on the Model of Serving "Agriculture, Rural Areas and Farmers" for Undergraduates of Gansu Agricultural University", Journal of Legal Export, vol. 2, pp. 63-65.

6. Qiliang, Gong and Qing, Qi (2017), "Problems and countermeasures faced by higher agricultural education under the new normal", Journal of Higher Agricultural Education, vol. 2, pp. 20-23.

Стаття надійшла до редакиї 03.09.2020 р.

\section{Науково-практичний жсурнал} «ЕКОНОМІКА ТА ДЕРЖАВА»

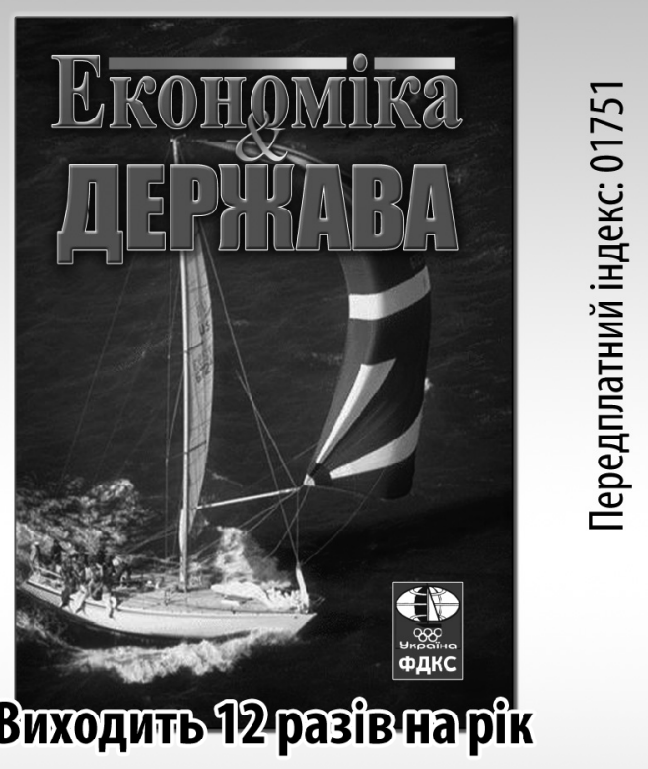

\section{наукове фахове видання України} 3 ПИТАНЬ ЕКОНОМІКИ

(Категорія «Б»)

Наказ Міністерства освіти і науки України від 28.12.2019 №1643

Спеціальності - 051, 071, 072, 073, 075, 076, 292. www. economy.in.ua e-mail:economy_2008@ukr.net тел.: (044) 223-26-28 (044) 458-10-73 